


\section{The United States Army War College}

The United States Army War College educates and develops leaders for service at the strategic level while advancing knowledge in the global application of Landpower.

The purpose of the United States Army War College is to produce graduates who are skilled critical thinkers and complex problem solvers. Concurrently, it is our duty to the U.S. Army to also act as a "think factory" for commanders and civilian leaders at the strategic level worldwide and routinely engage in discourse and debate concerning the role of ground forces in achieving national security objectives.
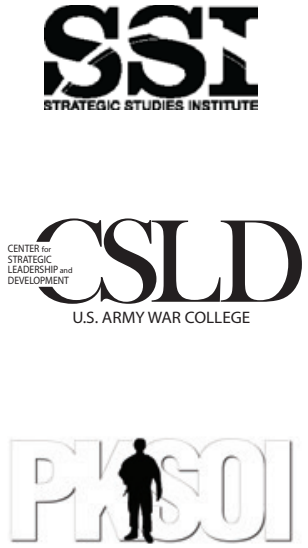

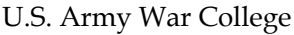

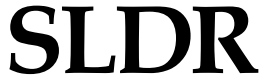

Senior Leader Development and Resiliency

The Strategic Studies Institute publishes national security and strategic research and analysis to influence policy debate and bridge the gap between military and academia.

The Center for Strategic Leadership and Development contributes to the education of world class senior leaders, develops expert knowledge, and provides solutions to strategic Army issues affecting the national security community.

The Peacekeeping and Stability Operations Institute provides subject matter expertise, technical review, and writing expertise to agencies that develop stability operations concepts and doctrines.

The Senior Leader Development and Resiliency program supports the United States Army War College's lines of effort to educate strategic leaders and provide well-being education and support by developing self-awareness through leader feedback and leader resiliency.

The School of Strategic Landpower develops strategic leaders by providing a strong foundation of wisdom grounded in mastery of the profession of arms, and by serving as a crucible for educating future leaders in the analysis, evaluation, and refinement of professional expertise in war, strategy, operations, national security, resource management, and responsible command.

The U.S. Army Heritage and Education Center acquires, conserves, and exhibits historical materials for use to support the U.S. Army, educate an international audience, and honor Soldiers - past and present. 


\section{STRATEGIC \\ STUDIES \\ INSTITUTE}

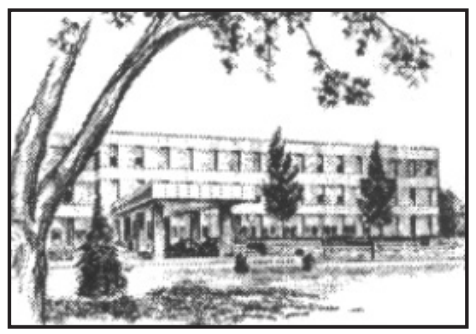

The Strategic Studies Institute (SSI) is part of the U.S. Army War College and is the strategic-level study agent for issues related to national security and military strategy with emphasis on geostrategic analysis.

The mission of SSI is to use independent analysis to conduct strategic studies that develop policy recommendations on:

- Strategy, planning, and policy for joint and combined employment of military forces;

- Regional strategic appraisals;

- The nature of land warfare;

- Matters affecting the Army's future;

- The concepts, philosophy, and theory of strategy; and,

- Other issues of importance to the leadership of the Army.

Studies produced by civilian and military analysts concern topics having strategic implications for the Army, the Department of Defense, and the larger national security community.

In addition to its studies, SSI publishes special reports on topics of special or immediate interest. These include edited proceedings of conferences and topically oriented roundtables, expanded trip reports, and quick-reaction responses to senior Army leaders.

The Institute provides a valuable analytical capability within the Army to address strategic and other issues in support of Army participation in national security policy formulation. 



\author{
Strategic Studies Institute \\ and \\ U.S. Army War College Press
}

\title{
MATURING DEFENSE SUPPORT OF CIVIL AUTHORITIES \\ AND THE DUAL STATUS COMMANDER \\ ARRANGEMENT \\ THROUGH THE LENS OF PROCESS \\ IMPROVEMENT
}

\author{
Ryan Burke \\ Sue McNeil
}

April 2015

The views expressed in this report are those of the authors and do not necessarily reflect the official policy or position of the Department of the Army, the Department of Defense, or the U.S. Government. Authors of Strategic Studies Institute (SSI) and U.S. Army War College (USAWC) Press publications enjoy full academic freedom, provided they do not disclose classified information, jeopardize operations security, or misrepresent official U.S. policy. Such academic freedom empowers them to offer new and sometimes controversial perspectives in the interest of furthering debate on key issues. This report is cleared for public release; distribution is unlimited.

This publication is subject to Title 17, United States Code, Sections 101 and 105. It is in the public domain and may not be copyrighted. 
Comments pertaining to this report are invited and should be forwarded to: Director, Strategic Studies Institute and U.S. Army War College Press, U.S. Army War College, 47 Ashburn Drive, Carlisle, PA 17013-5010.

\section{$* * * * *$}

This manuscript was funded by the U.S. Army War College External Research Associates Program. Information on this program is available on our website, www.StrategicStudies Institute.army.mil, at the Opportunities tab.

$* * * * *$

All Strategic Studies Institute (SSI) and U.S. Army War College (USAWC) Press publications may be downloaded free of charge from the SSI website. Hard copies of this report may also be obtained free of charge while supplies last by placing an order on the SSI website. SSI publications may be quoted or reprinted in part or in full with permission and appropriate credit given to the U.S. Army Strategic Studies Institute and U.S. Army War College Press, U.S. Army War College, Carlisle, PA. Contact SSI by visiting our website at the following address: www.StrategicStudiesInstitute.army.mil.

$* * * * *$

The Strategic Studies Institute and U.S. Army War College Press publishes a monthly email newsletter to update the national security community on the research of our analysts, recent and forthcoming publications, and upcoming conferences sponsored by the Institute. Each newsletter also provides a strategic commentary by one of our research analysts. If you are interested in receiving this newsletter, please subscribe on the SSI website at www.StrategicStudiesInstitute.army.mil/newsletter.

ISBN 1-58487-673-5 


\section{FOREWORD}

During large-scale emergencies or disasters, National Guard forces regularly operate alongside Active Component forces in response to requests from civil authorities. In an attempt to promote unity of effort between state-controlled National Guard and Active Component forces, states and the Department of Defense agreed to use dual status commanders - military commanders authorized by law to serve in both state and federal statuses simultaneously - as the primary command and control mechanism during unplanned incident response operations. This unique command arrangement was used for the first time in response to an unplanned incident during Hurricane Sandy in October 2012. Though the arrangement worked well in many ways, there are definitely opportunities for improvement.

Using their recent Strategic Studies Institute study evaluating the use of dual status commanders during Hurricane Sandy, Mr. Ryan Burke and Professor Sue McNeil offer suggestions to mature dual status commander operations through the application of process improvement concepts. They take a unique approach to their analysis and propose a series of examples and recommendations intended to illustrate a new way of both diagnosing and improving operational performance during these complex missions.

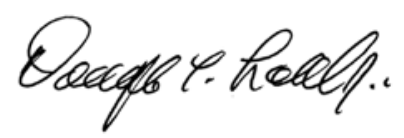

DOUGLAS C. LOVELACE, JR.

Director

Strategic Studies Institute and

U.S. Army War College Press 



\section{ABOUT THE AUTHORS}

RYAN BURKE is currently a doctoral candidate at the University of Delaware with a research focus on defense support of civil authorities. Before starting his Ph.D., Mr. Burke was a captain and logistics officer in the U.S. Marine Corps where he served as a landing support platoon commander, operations officer, and company commander at Camp Lejeune, NC. He then served as the Deputy Marine Officer Instructor for the Philadelphia Naval ROTC Consortium at the University of Pennsylvania. After leaving the Marines, he worked as a Senior Consultant and Logistics Analyst for Booz Allen Hamilton supporting several Department of Defense projects both in the Pentagon and aboard Marine Corps Base at Quantico, VA. Mr. Burke attended Penn State University on an NROTC scholarship, graduating with a degree in crime, law, and justice, and a minor in military studies. He holds a master of science degree in homeland security from Saint Joseph's University.

SUE MCNEIL is Professor of Civil and Environmental Engineering and Public Policy and Administration at the University of Delaware. She also directs the Graduate Program in Disaster Science and Management and is the former Director of the Disaster Research Center at the University of Delaware. Professor McNeil has extensive experience working with transportation organizations and agencies on multicriteria decisionmaking, performance measures, target setting, and asset management. Dr. McNeil has served as a member of the Executive Committee of the Transportation Research Board and a member of the Board on Infrastructure and the Constructed Environment. She chaired the Transportation Research Board's Commit- 
tee on Asset Management from 2004 to 2010 and is an Emeritus Member of the committee. She is a founding Associate Editor for the American Society of Civil Engineers' Journal of Infrastructure Systems and became the Editor-in-Chief in July 2010. Professor McNeil is a registered professional engineer. 


\section{SUMMARY}

The role of the military during homeland defense and civil support operations has significant strategic implications for U.S. national security efforts. Considerations for the future employment of Active Component forces during missions in the homeland have evolved into a major topic of conversation among policymakers and military strategists alike. In this context, there is a philosophical conflict between federalism and state sovereignty that continues to present itself as an impediment to success. Balancing the institutionally divergent approaches to achieve a unified, efficient, and effective response continues to prove problematic. The dual status commander (DSC) initiative offers a coordination mechanism intended to address the challenges of unity of effort between state and federal military response activities. However, there are numerous gaps in the available DSC guidance, which leads to increased complexity and confusion during domestic disaster response.

This monograph introduces process improvement strategies focusing on the DSC construct in New York during Hurricane Sandy. It builds on our previous Strategic Studies Institute monograph documenting the DSC-led response to Hurricane Sandy in New York. Using the data collected during the Sandy case study as a basis for analysis, the monograph discusses the potential role of process improvement techniques as a method for improving unity of effort between state and federal military forces under the DSC construct for no-notice/limited-notice incident response. As part of our argument, we assess the application and utility of various process improvement methods and present examples of how such methods can 
be used to improve civil support missions. Based on the recommendations from the Sandy case study, we conclude by presenting a brief description of three conceptual process models mapped to specific challenges of a DSC-led joint task force. These process models identify essential tasks and key requirements specific to a key process during a DSC operation. In doing so, the models provide examples - not fully developed models - of alternative methods to guide the progression of operational maturity during domestic disaster response. As such, organizations like the U.S. Army Training and Doctrine Command, the Office of the Secretary of Defense, U.S. Army North, and U.S. Northern Command should consider integrating process improvement concepts and techniques into future DSC doctrine, policies, guidance, and operational tactics, techniques, and procedures. Using the concepts presented here as a method for improvement, we argue, will provide a practical tool for enhancing the efficiency and effectiveness of this critical coordination mechanism well into the future. 


\section{MATURING DEFENSE SUPPORT OF CIVIL AUTHORITIES \\ AND THE DUAL STATUS COMMANDER \\ ARRANGEMENT \\ THROUGH THE LENS OF PROCESS \\ IMPROVEMENT}

\section{INTRODUCTION}

Combat operations require swift decisionmaking, often with less information than is necessary to make an informed decision. For these reasons, military commanders and planners regularly rehearse, train, exercise, and simulate combat scenarios so they are better prepared to face such challenges in real-world situations. However, the U.S. military has an additional mission capability that regularly requires a similar sense of urgency to combat operations. Civil support operations in response to emergencies or disasters, while mostly lacking the inherent dangers of combat, present an equally challenging operational environment full of legal, financial, and even political barriers unique only to domestic missions.

Known as Defense Support of Civil Authorities (DSCA), the U.S. military's domestic disaster response capability is robust. During incidents of great magnitude or duration, when local and state authorities are overwhelmed or unable to respond as needed, civil authorities sometimes request assistance from the Department of Defense (DoD). These DSCA operations span a wide range of scenarios, including response to natural and man-made disasters, civil disturbances, terrorism, and other significant incidents. In the early stages of response operations, lives and property can be at risk, often requiring swift decisionmaking with 
limited information, similar to combat operations. However, while combat operations must be undertaken with consideration for the defined rules of engagement and laws of war, these are less restrictive, arguably, than the laws and policies governing the actions of U.S. military forces in a domestic capacity.

DSCA operations occur within a complex web of local, state, and federal laws, policies, and regulations, many of which are rooted in the founding principles of this nation and its rich history. DSCA presents a challenging operational environment for military leaders requiring effective navigation of the aforementioned laws, policies, and in some cases, politics. While military leaders value the ability to maintain a flexible, adaptive, and agile response capability, there are, for better or worse, bureaucratic obstacles in the form of processes and procedures that must be considered when operating domestically in support of lead Federal civil authorities. As an added challenge, the incidents requiring Federal military assistance typically involve state and federal military responses from National Guard forces and Active Component forces. Despite similar operational capabilities, state National Guard forces and Active Component forces operate under distinctly different sets of laws and policies, which only serve to further complicate an already difficult mission.

Throughout recent history, we have seen some of the challenges faced by National Guard and Active Component forces supporting civil authorities simultaneously. In 2004, during the G-8 Summit in Sea Island, Georgia, DoD and the states adapted a new command mechanism originally designed for blended units to improve unity of effort between National Guard and Active Component forces supporting civil authorities. 
Six years later, the Council of Governors facilitated a solution to a long-standing debate between state governors and DoD over domestic command and control of the Armed Forces when operating in their states: The governors and the Secretary of Defense (SECDEF) agreed to utilize the dual status commander (DSC) for disaster responses. In addition, the governors and the SECDEF agreed to propose legislative language in the 2012 National Defense Authorization Act (NDAA) codifying in law that the establishment of a dual status commander is the "usual and customary" command and control arrangement during the simultaneous employment of National Guard and Active Component forces in disaster response scenarios. ${ }^{1} \mathrm{~A}$ DSC is a "military commander who may, in accordance with the law, serve in two statuses, Federal and State, simultaneously while performing the duties of those statuses separately and distinctly." ${ }^{2}$ Principally designed as an enhanced unity of effort mechanism, the DSC construct allows a single military commander to command both National Guard forces on behalf of a Governor, and Active Component forces on behalf of the President, the SECDEF, and a supported Combatant Commander, when both are supporting civil authorities simultaneously.

This unique command arrangement has been used successfully since 2004 for planned national security special events such as national political conventions, international presidential summits, and the 2013 Super Bowl. ${ }^{3}$ However, Hurricane Sandy in October 2012 was the first use of National Guard and Active Component forces working under a DSC for a no-notice/ limited-notice ${ }^{4}$ incident. ${ }^{5}$ Sandy provided our first opportunity to witness the DSC construct in action during an unplanned response effort. As expected, there 
were several successes with this first time implementation that, in the minds of some, validated the concept and encouraged future use. ${ }^{6}$ Conversely, the response experienced some notable challenges.

Each of the Armed Services have systematic ways of capturing lessons learned from training and operations in order to build on the past and improve operations in the future. These Lessons Learned programs are quite valuable. They offer insight to their respective service components to help improve future mission performance through concept and doctrinal changes and recommendations. Sometimes, however, these recommendations and changes are not integrated into future operations due to an ill-defined, or ineffective, method of doing so. Without a defined method to integrate these recommendations, there is no way to promote consistent and continuous improvement of these complex operational processes. There is a need, then, to develop a tool or method that can be used to consolidate recommended best practices into usable models able to guide future operational decisionmaking. One approach worth considering is to apply process improvement strategies to the complexities of DSCA in order to develop a model to improve DSC operations. $^{7}$

Whereas military operations lack structured improvement methods, defense contracting and similar DoD business operations regularly employ process improvement strategies as a way to enhance their operational performance and accountability. Process improvement strategies are structured methods to assess processes in terms of both strengths and weaknesses. These strategies also guide users by helping them chart a path for addressing issues while preserving desirable qualities of a given process or system. Most 
process improvement strategies engage stakeholders and develop supporting documentation for accountability. With its rich history of research literature supporting its use and application within software engineering, software development, manufacturing, and business operations, process improvement is a proven approach to enhance and mature complex operations. ${ }^{8}$ DoD currently uses structured process improvement techniques and methods in a range of functions as a way to monitor performance, identify areas of weakness, and steer improvement efforts toward performance enhancement and maturity.

While there are different approaches, in their most basic form, process improvement techniques focus on reducing waste and improving productivity through the identification and performance of consistent, repeatable, and predictable practices. By deconstructing complex processes into individual and related practices or actions, process improvement offers users a tool for modeling the complexities of their processes into workable goals and practices. Given the potential utility of process improvement coupled with the inherent complexities of DSCA operations under a dual status commander, these same process improvement techniques currently used and endorsed by DoD in nonoperational department activities can provide an ideal platform to launch a structured improvement plan aimed at maturing complex civil support operations under the DSC construct.

\section{COMPLEXITIES OF CIVIL SUPPORT OPERATIONS}

The framers of the U.S. Constitution wrote it in such a way as to deter or restrict a single governing body 
from exercising unregulated control over its constituents. Whereas the 18th century English government used the military as a means of power projection over its citizenry, the architects of the Constitution, having declared their independence from an overriding governing body, sought to avoid similar abuse of governmental powers. As a result, the Constitution embraces a federalist construct with language articulating the separation of powers between three branches of government and shared powers with individual states. Per Article $\mathrm{X}$ of the Constitution, any such powers not given to the federal government under the Constitution are reserved to the states. Some of the key language in this regard outlines the powers and limitations governing the role of the military in domestic operations. As the supreme law of the United States, these constitutional authorities and restrictions must be understood as they provide the very foundation for the use of military forces on domestic soil. Such limitations and restrictions also serve to complicate domestic military operations by entrenching command decisionmaking in a complex set of laws, policies, and formal regulations, each of which must be considered during the conduct of DSCA and National Guard support to civil authorities.

Under the federalist construct, states and the federal government are divided but share certain powers and authority. Among the many divisions of power and authority, the role of the military in domestic capacities is one of the most significant. The Constitution provides the basis for governing domestic state and federal military actions. It gives powers to the states to maintain a militia, or National Guard. ${ }^{9}$ It also allows the President to call state militias into federal service under specific circumstances. ${ }^{10}$ These declarations are 
upheld by specific laws in the U.S. Code and ensure a clear and distinct military line of authority between the states and the national government. Other laws further regulate domestic military action and must be considered during civil support operations.

The Posse Comitatus Act specifically prohibits the Armed Forces from performing law enforcement activities on domestic soil, unless specifically authorized by Congress (e.g., supporting the Department of Justice in emergency situations involving weapons of mass destruction pursuant to section 382 of title 10, U.S. Code). However, this law does not apply to National Guard forces in State Active Duty or Title 32, U.S. Code (state controlled; federally funded), status. The Insurrection Act of 1807, however, authorizes the President to deploy the Armed Forces in a law enforcement capacity within the United States in order to suppress an insurrection, rebellion, domestic violence, unlawful combination, or conspiracy, or to repel an invasion. The Insurrection Act also authorizes the President to deploy the National Guard in a federal status in a similar manner. Beyond these notable laws, several additional laws and numerous other policies and regulatory guidelines also influence domestic military operations. Simply put, domestic Federal military actions are governed by a complex series of laws, policies, and procedures that often contribute to inefficient and ineffective operations during times of critical need.

In recent years, the DSC concept has generated legislative and political momentum and has become the usual and customary command and control mechanism for simultaneous military state and federal response missions. Hurricane Sandy was the first opportunity to see the DSC concept used in response 
to a no-notice/limited-notice incident. The operation demonstrated some notable successes, but also encountered numerous challenges that process improvement techniques can help to address.

\section{HURRICANE SANDY AND THE DUAL STATUS COMMANDER}

Hurricane Sandy made landfall near Brigantine, $\mathrm{NJ}$, at approximately 11:30 p.m. on October $29,2012 .{ }^{11}$ In response to governors' requests, the DoD approved DSC authorizations for several states along the east coast. Of the five states authorized to use DSCs, only two DSCs were activated-New York and New Jersey - to command National Guard and Active military responders. ${ }^{12}$ Despite successful efforts to use a DSC during planned operations since 2004, as well as its recent adoption in the 2012 NDAA, the DSC had not been used during an unplanned disaster response prior to Hurricane Sandy. ${ }^{13}$ Both successes and previously anticipated areas of weakness marked the inaugural employment of the DSC construct during an unplanned incident. A report by the Government Accountability Office (GAO) on October 26, 2012-10 months after the approval of the 2012 NDAA and 4 days before Hurricane Sandy's landfall-addressed the notable gaps in homeland defense and civil support guidance with specific emphasis on the need to address dual status commander policies and procedures:

gaps in guidance remain because DOD has not yet developed comprehensive policies and procedures regarding the use and availability of dual-status commanders, including specific criteria and conditions for when and how a state governor and the Secretary of 
Defense would mutually appoint a commander.... As a result, DOD's ability to adequately prepare for and effectively use dual-status commanders for a range of civil support events, including those affecting multiple states, may be hindered. ${ }^{14}$

As if foreshadowing future events, GAO's comments issued days prior to Sandy offered an accurate prediction of the resulting state and federal military responses under the dual status commander. While there were several notable successes, the state and federal military responses to Sandy experienced numerous challenges. Aside from the first use of a DSC during an unplanned response, facilitating unity of effort between Active Component and National Guard forces during the Sandy response required a multistate coordination effort unlike anything previously encountered. ${ }^{15}$ This necessitated the establishment of a temporary multiservice, multicomposition Joint Task Force (JTF) in New York combining elements of the Active Components (Navy, Marine Corps, Army, and Air Force) and the National Guard (Army and Air). As a result of the complex JTF structure during Sandy, the DSC in New York dealt with coordination and communication issues, operational and tactical confusion, and significant management challenges throughout the duration of the 2-week response period.

As one of the many examples of confusion less than a week into the response operation, the U.S. Marine Corps - at the request of a New York/New Jersey Port Authority official-deployed a detachment of Marines to Staten Island unbeknownst to the NY DSC. ${ }^{16}$ Since a civil authority specifically requested the Marines to come ashore, this technically authorized them to deploy without first informing the DSC or his 
staff. ${ }^{17}$ The Marines' landing created confusion on the part of the DSC. According to multiple DoD after action reports, tactical Active Component military commanders were not initially aware that a DSC had been activated, nor did they know how to establish contact with his staff. ${ }^{18}$ The tactical confusion among Active Component military commanders points to the lack of process guidance for such actions during DSC-led responses. In addition, there were several additional instances of confusion with regard to the mission assignment process.

In order to approve a funded mission assignment for Federal military support, requests for assistance must originate from a lead Federal civil authority such as the Federal Emergency Management Agency (FEMA), which, in accordance with the Stafford Act, acts on requests for support from a state. States request federal support from the lead federal agency (LFA) for the particular operation. If necessary, the LFA requests DoD support. DoD support, while inclusive of military force capability, is not limited to the Armed Forces. The U.S. Army Corps of Engineers and the Defense Logistics Agency can provide support, as we saw during the Sandy response. Conceptually, this bottom-up process ensures that officials use all available local and state resources (including the National Guard) before requesting Federal support. In some cases during Sandy, this process was not followed as described. On November 2, for example, U.S. Northern Command (NORTHCOM) published a fragmentary order ${ }^{19}$ directing Active Component forces to:

- Get missions;

- Do not wait for mission assignment paperwork; and,

- Apply total force capabilities to accomplish those missions..$^{20}$ 
As part of most military operations, commanders at all levels develop and issue operations orders detailing specific items relevant to a particular operation. Most operational orders follow a basic five-paragraph format and include such sections as situation, mission, execution, administration/logistics, and communications. These orders provide the needed operational guidance and intent to allow commanders at all levels to guide their unit activities in a manner that contributes to the achievement of the tactical, operational, and strategic objectives of the operation. Fluid and dynamic situations often require modifications to published orders. In the case of Hurricane Sandy, NORTHCOM issued the above fragmentary order in response to a growing sense of urgency to integrate Federal military forces into the response operation. Normally, this aggressive top-down approach would not present an issue for a DSC. However, when military units provide response support outside of the command and control of the DSC - as they did during Sandy - it creates coordination challenges. The resulting actions of Active Component forces operating within the joint operations area but external to the DSC's command and control, in this case led to increased confusion as the DSC had no way of tracking the actions of some Active Component forces.

If we use examples such as this and others that occurred during Sandy, we can analyze the state and federal military responses and develop a basis of knowledge for improving future missions through the lens of process improvement. Fortunately, there are numerous lessons learned from which we can base our future process improvement efforts. 


\section{Post-Sandy Lessons Learned.}

No matter the source, there is an apparent consensus across DoD that command, control, and management of forces presented one of the most challenging aspects of the Sandy DSCA operation. ${ }^{21}$ Despite the positive image portrayed in most media accounts of the military's role during the storm response, actual military and government after action reports provide more objective, self-critical assessments of performance. These documents highlight the coordination issues between National Guard and Active Component forces, while addressing the apparent lack of familiarity regarding DSC arrangements. ${ }^{22}$ Outside of the military, the Government Accountability Office (GAO) produced a comprehensive post-Sandy assessment of DoD's complex catastrophe planning. In their 2013 review of the response to Hurricane Sandy, the GAO noted that "the roles and responsibilities of the dual status commander, joint coordinating element, and defense coordinating officer were unclear." ${ }^{23}$ According to the report, this issue and others created confusion among the responding military forces that hindered the DSC's ability to establish unity of effort, which is the principal intent of the DSC arrangement during such missions.

The 2013 report affirms what the GAO previously reported in 2012 prior to Sandy: There is a lack of sufficient DSC policies and procedures that leads to questions and confusion during certain operational situations employing DSC architecture. ${ }^{24}$ Our Sandy monograph notes the insufficiencies of the military responses to Hurricane Sandy in New York. ${ }^{25}$ As part of this study, we provided a series of strategic, operational, tactical, legislative, and policy-specific recom- 
mendations for consideration. Among the strategic and operational recommendations, we suggest:

1. Strategic changes to future DSCA operations through eliminating the Joint Coordinating Element (JCE), which was placed in command over the NY and NJ DSC and caused command and control issues. To further improve coordination, we also suggested appointing a Defense Coordinating Officer in Charge (DCOIC) when more than one Defense Coordinating Officer (DCO) is involved in a state response, as we saw in Sandy.

2. A predetermined Active Component force integration period when using a DSC, especially during a limited-notice event like a hurricane.

3. A mechanism similar to one in the Joint Staff Execution Order (EXORD) $)^{26}$ for authorizing the DSC to assume tactical control of Active Component forces in his/her area of operational responsibility $(\mathrm{AOR})^{27}$ in order to promote unified efforts.

From a policy and legislative perspective, we argue for several changes:

1. Revise the current immediate response authority policy, including revising and clarifying the definition of "civil authority."

2. Expansion of 10 U.S.C. $\$ 12304 a^{28}$ to include specific circumstances when the Army Reserve, Navy Reserve, Marine Corps Reserve, and Air Force Reserve can be sourced for support during a disaster response.

3. Revision of 32 U.S.C. $\S 502 \mathrm{f}^{29}$ with more restrictive operational triggering criteria for civil support operations in order to avoid further abuses of this authority. 
These recommendations, in addition to others noted in the Sandy monograph, illustrate the range of complexities involved in not only DSC-led response operations, but the larger DSCA and National Guard support operational landscape. Specifically to the argument here, the fluidity and uncertainty of DSC missions lends itself well to applying process improvement methods to enhance future missions. Using some of the recommendations noted in our previous case study, we demonstrate how process improvement can be used to incorporate the recommendations and generate noted improvements in future DSC-led missions.

\section{DUAL STATUS COMMANDERS: SUPPORT FOR NEEDED IMPROVEMENTS}

Hurricane Sandy gave us an opportunity to test the DSC arrangement during a no-notice/limited notice incident in support of civil authorities. While some successes were evident, we believe there is room for improvement in the way the military executes DSCA operations under the DSC arrangement. In addition to its adoption as the usual and customary disaster response command arrangement via the 2012 NDAA, many senior military commanders publically support the DSC concept. During the Sandy response, Generals Charles Jacoby and Frank Grass, NORTHCOM Commander and Chief of the National Guard Bureau (NGB), respectively, affirmed this in an article following the Sandy response:

While this inaugural use of Dual-Status Commanders wasn't flawless, in the end we can say with conviction that the concept works. It is simply the best command 
and control construct that exists for responding effectively and efficiently to complex disasters, because it can bring the full weight of the DoD response to the worst man-made or natural disasters while maintaining the authority of state and local governments. ${ }^{30}$

As the Chief of the NGB during the response to Hurricane Katrina, Lieutenant General H. Steven Blum (USA, Ret.), along with Lieutenant Colonel Kerry McIntyre (USA, Ret.) of the Maryland Army National Guard, noted the benefits of the DSC arrangement compared with the traditional parallel model of command and control in which state National Guard and Active Component forces operate simultaneously but under separate commands. In their 2012 study based largely on personal experience during Katrina which was published by the Strategic Studies Institute (SSI), the authors contended that the operational processes governing the military responses under a DSC work, but need to be improved:

Dual status command works. It should be the rule, not the exception; and better methods must be developed for placing useful military capabilities under dual status command, when requested and if available, for homeland response. ${ }^{31}$

Based on the 2012 NDAA legislation and the endorsement of many senior military and DoD leaders, the DSC construct will remain a central focus of current and future efforts to improve domestic response capabilities of the U.S. military. There is a need, then, to mature this command construct in order to attain and maintain the level of proficiency and effectiveness expected in future response missions. However, improving such a complex mission capability under a 
seldom-used command arrangement is quite literally easier said than done.

Simultaneous DSCA and National Guard support of state civil authorities occurs within a complex decisionmaking environment that must integrate legal, political, financial, and bureaucratic considerations into nearly every command decision. We can continue to write and publish policies and laws in the hopes that our commanders will consider each appropriately prior to making command decisions during uncertain situations. However, disaster operations often require a sense of urgency in which bureaucracy only serves as a hindrance. In these cases, policies, and in some cases law, tend to be ignored, marginalized, or simply forgotten. It is a rare commander who will delay a needed operational decision in order to consult a manual or other lengthy reference publication. In light of this, what we need is a tool applicable to the urgency and complexity of no-notice/limited-notice operations that still offers commanders a valuable utility. Such a tool will distill the labyrinth of policies, procedures, doctrine, and law into a simplified map of mission-essential tasks worthy of the commander's consideration. This can be achieved through the application of process improvement strategies. Using process improvement, we can build such a tool that provides commanders with the information necessary to ensure deference to the necessary laws and policies governing military civil support missions without sacrificing speed, efficiency, effectiveness, or urgency.

\section{Why Process Improvement?}

Process improvement is "a program of activities designed to improve the performance and maturity of an organization's processes, and the results of such 
a program." 32 Process improvement advocates argue that the quality of a product or service is proportional to the quality of the process. ${ }^{33}$ In the most basic sense, process improvement offers users a structured approach to move from ad hoc and immature processes to disciplined, mature processes and enhanced performance. In order to mature processes and improve product or service delivery, process improvement strategies emphasize identification and performance of consistent practices deemed essential to providing quality products or services. Business organizations that employ process improvement techniques do so in order to limit time spent performing unnecessary or wasteful practices, while ensuring essential tasks or practices are not only performed, but consistently and predictably repeated. Through the diagnosis and assessment of critical practices, process improvement is a modification for most business organizations. By identifying wasteful practices for removal, and essential tasks for consistency and repeatability, businesses are better able to improve the quality of their services and product delivery. Companies including Lockheed Martin, Raytheon, Boeing, IBM, Booz Allen Hamilton, Federal Express (FedEx), and other industry leaders employ process improvement methods as a way to enhance product and service delivery. ${ }^{34}$ As such, there are several examples of the benefits of process improvement to support our argument. The next section offers a brief example of how FedEx used process improvement techniques to solve a service delivery issue and improve overall operational performance. This example is relevant to the current argument because it illustrates how an operationallyoriented service provider was able to apply similar concepts and techniques as presented in this analysis 
to improve a critical operational function and mature its delivery capabilities. While the circumstances and specifics are different, we believe this offers support to our argument and its potential application to military operations.

\section{FedEx and Process Improvement.}

According to a senior executive at FedEx, one of the company's top business priorities is to "always seek to improve our processes." ${ }^{35}$ As a leader in global package delivery services, the complexities of FedEx's day-to-day operations rival any in the service delivery industry. As a result, the company regularly looks for ways to maintain or improve its market share by improving processes and overall performance. FedEx employs a cadre of professional analysts whose primary role is to diagnose processes by identifying areas of weakness or inefficiency, as well as best practices. These analysts then apply a range of process improvement strategies to re-engineer critical processes aimed at improving efficiency and effectiveness of their parcel services.

In 2007, for example, FedEx analysts noted a sharp rise in service demand along with a growing trend among customers for greater access to package tracking and location services. After providing improved tracking capabilities, FedEx noted an increase in customer complaints regarding delivery delays, as their customers were able to see real-time status updates including arrival and departure times in various sorting facilities located along a shipment route. What was originally intended to be an enhancement in customer satisfaction resulted in a growing dissatisfaction over perceived delays and inefficiencies in package de- 
livery times. In order to meet evolving customer demands for speed and efficiency, while also noting an insufficient data tracking capability, FedEx used process improvement methods to diagnose and enhance their critical sorting processes. In doing so, FedEx identified inefficiencies in its parcel tracking system related to increased volume and the system's inability to effectively service growing requirements. As a solution, the company deployed a new internal operating system to enhance parcel tracking and data processing at its many sorting facilities. This improved operating system enhanced FedEx's receiving and sorting processes for standard ground packages (nonpriority). As a result of this process improvement approach to meet a growing customer demand, FedEx Ground lowered its average parcel delivery time in over half of its network by nearly 24 hours over a 3 -year period. ${ }^{36}$

\section{Process Improvement in the Department of Defense.}

FedEx is just one example of the many companies and organizations worldwide that employ process improvement strategies as a way to improve their business practices, operations, and profitability. While the private sector uses process improvement as a means to generate profit, process improvement can-and does-provide a benefit to government services as well. As the largest Federal department in terms of budget and personnel, ${ }^{37}$ DoD regularly requires improvement to its various processes and programs. As such, process improvement is not foreign to DoD. Military personnel in certain occupational specialties are familiar with process improvement methods and techniques including Lean Six Sigma (LSS) and Ca- 
pability Maturity Models-Integrated (CMMI), among others. Recognizing the importance and utility of these methods, DoD, in 2007, established the Office of Continuous Process Improvement (CPI) and LSS within the Office of Business Transformation and housed it under Acquisition, Technology, and Logistics. CPI/ LSS' primary mission is to ensure the integration of process improvement methods into current business operations within DoD. ${ }^{38}$ By integrating process improvement methods into defense business operations, DoD has a vehicle for business process optimization through the identification and reduction of wasteful practices. Process improvement methods such as LSS and CMMI provide DoD with the necessary techniques to diagnose and improve critical business processes and meet mission requirements. As such, these techniques are used throughout $\mathrm{DoD}$ in a variety of capacities, albeit mostly administrative in nature.

Other process improvement-based assessment practices like the Manager's Internal Control Program, the Commander's Evaluation Program, and similar continuous improvement approaches are regularly applied to improve the efficiency and effectiveness of business practices within DoD. Given the ongoing application of process improvement techniques to enhance administrative elements of $\mathrm{DoD}$, as well as the proven application to private sector operations like FedEx, we argue that these same principles can be used to mature military operations. With a degree of creativity and flexibility, DoD can apply these proven techniques to their operational environment as a way to measure current performance and improve future performance. In order to identify the best process improvement technique for application to the complexities of military civil support operations, it is necessary 
to understand the key elements of process improvement and its many alternative approaches.

\section{Key Elements of Process Improvement.}

Since there are several process improvement alternatives - each with a specific concentration - it is helpful to discuss some of the most common approaches and the potential application to military operations. Early process improvement literature dates back to the 1930s and the work of Walter Shewhart. Shewhart, whose work emphasized quality control principles, is credited with creating the "Plan Do Check Act" concept-or the Shewhart Cycle-which is now used throughout managerial mediums as a simple means for improving procedures. ${ }^{39}$ Shewhart's early work was expanded by modern process improvement scholars and has since evolved into a research area casting a wide scope across the performance management and engineering fields alike. Unlike performance management approaches that are focused on achieving predetermined measurable results or outcomes, process improvement - in contrast-emphasizes adherence to established steps or procedures to improve the quality of a product or service. ${ }^{40}$ In other words, "the quality of a system or product is highly influenced by the quality of the process used to develop and maintain it." ${ }^{41}$ There are several methods for process improvement that have been applied to organizations seeking to improve the delivery of their products and/or services. Some of the more commonly used approaches include Total Quality Management, ${ }^{42}$ Lean ${ }^{43}$ Six Sigma, ${ }^{44}$ the IDEAL Model ${ }^{45}$ and maturity models. ${ }^{46}$ 
Table 1 presents some common process improvement methods in terms of the focus area, purpose, and features of the method. Each alternative brings a unique focus and approach to improving processes. Despite their differences, the strategies offer users a structured method to improve their processes, regardless of functional area. Some of the model-based strategies, like maturity models, facilitate the consolidation of best practices into a single medium for all users. Having a model that articulates user-defined best practices or essential tasks helps organizations work smarter, not harder, and with improved consistency. So, the applied benefit of process improvement is potentially significant. However, most of the above approaches are grounded in software engineering and other well-defined practices and are therefore best suited for the inherent predictability of such functions. This makes adapting process improvement concepts and techniques challenging for the operational uncertainty and fluidity of military operations. Despite these challenges, we argue that process improvement can be adapted for military operations and result in tangible enhancements. 


\begin{tabular}{|c|l|l|l|l|l|}
\hline \multicolumn{2}{|c|}{ Process Improvement Alternatives } \\
\hline Method & $\begin{array}{l}\text { Total Quality } \\
\text { Management }\end{array}$ & \multicolumn{1}{|c|}{ Lean } & \multicolumn{1}{c|}{ Six Sigma } & \multicolumn{1}{c|}{ IDEAL } & \multicolumn{1}{c|}{$\begin{array}{c}\text { Maturity } \\
\text { Models }\end{array}$} \\
\hline Focus Area & $\begin{array}{l}\text {-Management } \\
\text { practices }\end{array}$ & $\begin{array}{l}\text {-Production } \\
\text { optimization } \\
\text { (manufacturing) }\end{array}$ & $\begin{array}{l}\text {-Process } \\
\text { variability } \\
\text { (minimize) }\end{array}$ & $\begin{array}{l}\text {-Process } \\
\text { definitions } \\
\text { and activities }\end{array}$ & $\begin{array}{l}\text {-Best } \\
\text { practices }\end{array}$ \\
\hline \multirow{3}{*}{ Purpose } & $\begin{array}{l}\text {-Continuous } \\
\text { improvement of } \\
\text { products/services }\end{array}$ & $\begin{array}{l}\text {-Eliminate } \\
\text { "waste" and } \\
\text { enhance } \\
\text { productivity }\end{array}$ & $\begin{array}{l}\text {-Remove defects } \\
\text {-Increase } \\
\text { repeatability/ } \\
\text { parity }\end{array}$ & $\begin{array}{l}\text {-Program } \\
\text { improvement }\end{array}$ & $\begin{array}{l}\text {-Process } \\
\text { mapping }\end{array}$ \\
\hline & $\begin{array}{l}\text {-Defined } \\
\text { requirements and } \\
\text { responsibilities }\end{array}$ & $\begin{array}{l}\text {-Value driven } \\
\text { practices }\end{array}$ & $\begin{array}{l}\text {-Quantifiable } \\
\text { performance } \\
\text { targets }\end{array}$ & $\begin{array}{l}\text {-Cyclical } \\
\text { process of } \\
\text { key activities }\end{array}$ & $\begin{array}{l}\text { /Target } \\
\text { profiles }\end{array}$ \\
\hline
\end{tabular}

Table 1. Variations in Process Improvement.

\section{Adapting Process Improvement for Operational Contexts.}

The use of DSCs during Hurricane Sandy highlighted the issues, gaps, and opportunities for improvement with regard to DSC arrangements during no-notice/limited-noticed incidents. There is an opportunity to learn from events like Hurricane Sandy and improve our knowledge and understanding of DSC structures and this critical mission-enhancing capability. Using process improvement techniques to guide these efforts is a unique approach worth considering. Given the systems and software engineering genesis of process improvement techniques, it is necessary to adapt them somewhat in order to maximize 
the benefit when applied to a less-structured operational context such as a DSCA mission.

The dynamic nature of DSCA operations requires mature capabilities representing information sharing, shared situational awareness, and social interaction; each of which must occur through both linear and vertical command hierarchies. The heterogeneous DSC construct involves several contributing elements, echelons, agencies, departments, and organizations in both state and federal operational chains of command. This requires an agile, coordinated response incorporating each entity and its respective capabilities. The DSC arrangement provides a command and coordination mechanism designed to help improve coordination processes across the federal-state authority boundary. Through enhanced information and knowledge sharing under the DSC construct, military commanders can achieve greater management effectiveness and governance. As a result, joint military operations seek to attain a network-centric and agile force structure during complex scenarios. The DSC construct is designed to facilitate such network-centric, agile operations involving multiple departments, agencies, and response organizations.

Knowing the complexities involved with military operations, doctrine argues for a mission command approach to leadership. ${ }^{47}$ This approach, more reflective of the modern, post-Vietnam era military, values decentralized control and empowering small unit leaders. Through this approach, commanders can articulate what needs to be done to subordinates while leaving the how, or the tactical level decisionmaking, up to the small unit leader. This approach also serves to minimize bureaucratic and procedural obstacles and offers the needed autonomy and flexibility for 
subordinate leaders to make split-second decisions without the constant need for approval from higher authority. While flexibility and agility are necessary ingredients for speed and effectiveness, military civil support operations often encounter challenges that process improvement techniques can help address.

As discussed previously, most process improvement approaches are designed to assess and improve the "assembly line" and predictable systems associated with software and systems engineering. These approaches focus on the identification of wasteful practices and direct their removal in order to improve system performance. The concept suggests that small changes or improvements in larger processes have a cascading effect on each subsequent process thereafter. This results in larger changes or improvements to predictable outcomes. Military operations of any kind are rarely predictable. While situations and scenarios can be anticipated with some accuracy, there is always a degree of uncertainty. As such, some process improvement techniques provide little utility for most military operations where flexibility and improvisation are highly valued. However, if we instead shift the focus of our improvement efforts to mapping the relevant processes and essential tasks associated, we can generate significant improvements in overall operational efficiency.

\section{BUILDING A PROCESS MODEL FOR DSCA OPERATIONS}

Military operations, especially DSCA missions, are unpredictable. The fluidity of an operational environment mandates flexibility, adaptation to the environment, and improvisation. With the inherent challenges in DSC-led DSCA operations, developing 
a process model as a tool to represent essential tasks and articulate relevant operational considerations would be a significant improvement. Since we know the DSC construct will be used again in future disaster response operations, we need to continue to learn from past operations and implement lessons learned. A DSC-led DSCA operation offers a semi-structured organizational arrangement to overcome some of the complexities associated with a multiauthority decision environment. Because of the organizational structure, there are repeatable tasks associated with a DSC, which, if performed consistently, will enhance operational performance in future missions. Improving the critical processes to execute DSC-led operations would further enhance the stability and predictability of interorganizational command, control, and coordination, and the ability of commanders to address a variety of environmental contingencies. With so many considerations and potential areas of challenge, identifying and documenting essential tasks for inclusion in a process model is a useful exercise aimed at improving complex military operational processes.

\section{Mission Essential Tasks and Process Mapping.}

To determine what is necessary for a DSC-led JTF - in either state or federal status - to function at its highest potential level of operational maturity during a disaster response, we must identify those essential tasks that must be performed during the conduct of the response. Drawing from established DoD concepts, identifying and listing essential tasks for consideration is similar to developing a Mission Essential Task List (METL). In operational contexts, METLs are tools that help commanders prioritize training activi- 
ties in preparation for combat operations. As described in the DoD METL Development Handbook, the premise centers on the identification of tasks that must be prioritized and performed in order to maximize the likelihood of accomplishing a given mission..$^{48}$ Mission essential tasks are activities that, when performed, are linked with successful outcomes. Multiple mission essential tasks form a METL. In other words, a mission essential task is a critical function that must occur in order to ensure completion of a particular mission.

While DSCA is a recognized mission capability of the U.S. military, few military units have core DSCA responsibilities. Beyond this, there are currently no DSCA-specific tasks listed in any joint METL within DoD. ${ }^{49}$ Since DSCA is a lower-level mission capability and priority for $\mathrm{DoD}$, there is no basis from which we can develop such METLs. However, this is an important consideration for improving future civil support operations; especially those combined state and federal missions using the DSC arrangement. The development of a DSCA or DSC-specific process model is an approach worth considering for future improvement efforts.

In order to determine appropriate METLs for inclusion in a process model, model creators seek industry or subject matter experts (SME) to provide input and recommendations through personal interviews and/or focus groups. SMEs help to identify the characteristics of effective processes and are therefore critical to the creation of a process model of this kind. As a DoD-endorsed and funded method of process improvement, a maturity model provides us with the ideal architecture to list DSC-specific METLs deemed necessary for a DSCA operation under a DSC. As opposed to other process improvement strategies gener- 
ally focused on achieving quantifiable business goals and objectives, maturity models emphasize individual task performance within structured levels as a means to generate comprehensive enhancement. With so many uncertainties, a one-size-fits-all approach is not suitable for DSCA. Due to the variations in scenarios during disaster response, there can be no single quantifiable measure of success applicable to all support operations. Therefore, the ideal process improvement strategy is one that identifies critical tasks for completion and focuses on the structured performance of such tasks. Maturity models offer commanders exactly that: a structured way of identifying, listing, and guiding the performance of critical tasks without the need to identify and work toward quantifiable and often irrelevant objectives.

Since maturity models emphasize specific practices or essential tasks, this process improvement strategy provides commanders with a singular comprehensive tool to view the complexities and the systematic interrelationships of a Federal JTF operation. The ability to view these tasks in a single tool gives commanders the benefit of having multiple task considerations in one location. Using a maturity model approach, we can build a DSC-led Federal JTF METL that will help commanders make more informed decisions by providing a structured list of tasks for consideration during the conduct of operations. In order to demonstrate the utility of such a tool, we use some of the proposed recommendations in our Sandy monograph as examples for guiding the development of simplified maturity models structured specifically for a DSC-led Federal JTF. The next section of this monograph uses three recommendations from our Sandy case study as examples to demonstrate the application of a basic maturity model for enhancing military operations. 


\section{RECOMMENDED PROCESS AND EXAMPLES}

In order to scope, design, and populate a usable maturity model, developers first need to determine the focus or purpose of the model. For the purposes of this discussion, we explain the development of a model scoped specifically to DSC-led Federal JTF processes. Once the scope has been determined, model developers need to collect data for the eventual design and population of the model. Suggested data collection methods include individual interviews and focus group interviews. ${ }^{50}$ In this example, developers must identify subject matter experts in DSC-led Federal JTF operations and request interviews and/or focus groups. Because maturity models contain specific practices determined to be critical for mature processes, interviews should include questions designed to illicit discussion and identification of essential task requirements during the conduct of DSC-led response operations. The interviewer, in relation to the intended utility of the model, determines the type, order, and content of these questions. After completing the interviews, developers must analyze the interview data in order to design and populate the maturity model according to SME input.

Most maturity models use a progressive scale - e.g., 1-5- to represent increasing levels of maturity. Maturity levels should be labeled with a short, descriptive term relevant to the collection of tasks contained in the given level. Some models, such as CMMI models, also include process areas, or clusters of related practices, within each maturity level to add structure to more complex representations. After determining the appropriate number of maturity levels and whether 
to include process areas, developers need to populate the model with SME input contained in the interview data. Identification and placement of essential tasks within the model initially depends on the developer's logic and rationale (content and placement is later validated by SME assessment with revisions performed as needed). If omitting process areas from the model, developers group the tasks so that they are representative of a sequenced, progressive process within each maturity level. After populating each maturity level and making revisions as needed based on SME input, the model can be tested in order to determine its suitability for future deployment.

To provide tangible examples of such a model, we used recommendations from our previous SSI case study on Hurricane Sandy to develop three processspecific maturity models. The three simplified maturity models each represent a structured list of mission essential task considerations in a consolidated format. Since these are recommendations contained in our case study, they are not actual processes currently practiced by the U.S. military. Therefore, source data is not available to create an accurate model that represents these processes. The models are hypothetical depictions of simplified maturity models designed to provide examples to support our discussion. The intent is to present process improvement concepts as an option for consideration in future operational enhancement efforts. Therefore, these models are not representative of the necessary size and scope otherwise required to fully represent the complexities of a DSC-led Federal JTF and its associated support operations. Rather, they illustrate how a simplified maturity model can be developed and used to guide the performance of singular tasks during the conduct of DSC-led State and Federal military support operations. 
By using a maturity model structure containing documented best practices or essential tasks, commanders can improve operational maturity by progressing from an undefined, ad hoc process to a welldefined, mature process. In addition, maturity models can be used as a metric of performance, or a rubric of sorts, for post-operation evaluations and after-action reporting. Using the model as a guide, commanders and their staffs can assess their performance by determining which tasks were or were not performed. This will serve as a metric that will provide a structured improvement plan through noting which practices were not performed. Regardless of intended application, the basic design and concept of a maturity model offers military units a useful method of mapping complex processes and increasing operational maturity.

\section{Maturity Model Example 1: Designate a Defense Coordinating Officer in Charge.}

Using basic tenets of process improvement techniques (process mapping, metric identification, etc.), we can develop a simplified maturity model with sequenced essential task considerations representing the Defense Coordinating Officer in Charge (DCOIC) assignment and activation process. ${ }^{51}$ Table 2 illustrates what this model might look like during a federally declared disaster (multistate or severe impact) where a DSC-led Federal JTF has been or will soon be established and multiple DCOs are involved (as in Hurricane Sandy). While such tasks may be accomplished without the aid of a model, developing and maintaining a defined tool of this kind will ensure that commanders and other key personnel possess a structured list of the essential tasks needed to activate and effectively employ a DCOIC. 


\begin{tabular}{|l|l|l|}
\hline \multicolumn{1}{|c|}{ Level 1-Reactive } & \multicolumn{1}{|c|}{ Level 2-Integrated } & \multicolumn{1}{c|}{ Level 3-Collaborative } \\
\hline $\begin{array}{l}\text { R1: Identify and activate } \\
\text { regional DCOs }\end{array}$ & $\begin{array}{l}\text { I1: Locate the Joint Field Office } \\
\text { (JFO) and Federal Coordinating } \\
\text { Officer (FCO) }\end{array}$ & $\begin{array}{l}\text { C1: DCO is integrated into State and } \\
\text { Federal processes for requesting } \\
\text { DoD Support }\end{array}$ \\
\hline $\begin{array}{l}\text { R2: Determine DCO } \\
\text { geographical areas of } \\
\text { responsibility }\end{array}$ & $\begin{array}{l}\text { I2: Determine DCO hierarchy } \\
\text { by 1) rank seniority or 2) billet } \\
\text { seniority }\end{array}$ & $\begin{array}{l}\text { C2: Deploy regional DCOs/ } \\
\text { Departments of Civil Engineering } \\
\text { (DCE) to pre-determined locations }\end{array}$ \\
\hline $\begin{array}{l}\text { R3: Establish DCE staff section } \\
\text { for each DCO }\end{array}$ & I3: Designate a DCOIC & $\begin{array}{l}\text { C3: Establish communications link } \\
\text { between regional DCOs, DSC JTF, } \\
\text { and DCOIC Information Operations } \\
\text { Technology (IOT) Mission } \\
\text { Assignment (MA) }\end{array}$ \\
\hline $\begin{array}{l}\text { R4: Identify location for } \\
\text { deployment of DCO/E staff } \\
\text { sections }\end{array}$ & $\begin{array}{l}\text { I4: Communicate DCOIC } \\
\text { designation to DCO/E staff } \\
\text { sections and DSC-led Federal } \\
\text { JTF }\end{array}$ & $\begin{array}{l}\text { C4: DCO/E located with key } \\
\text { interagency organizations that they } \\
\text { support, i.e. FEMA }\end{array}$ \\
\hline
\end{tabular}

\section{Table 2. DCOIC Deployment Maturity Model.}

The utility of the model is such that it provides a guided progression of activities from a reactive level of maturity-unplanned and ad hoc - to a collaborative maturity level. The different levels of maturity (Reactive, Integrated, Collaborative), suggest how the process can evolve from an ad hoc process to a unified process where necessary personnel, units, agencies, and organizations unify their efforts in order to achieve a common goal. In the example below, the military end-user achieves a collaborative maturity level 3 (most mature) by performing and documenting all listed tasks in Levels 1, 2, and 3. While the tasks do not necessarily have to be performed in order, Level 3 tasks cannot be performed without first accomplishing those tasks listed in Levels 1 and 2. (Users employ the same maturity progression process described in Table 2 for all examples contained in this monograph). 


\section{Maturity Model Example 2: Establish an Initial Title 10 Integration Period.}

In another example of maturity model application related to our Sandy case study recommendations, we model the essential task considerations needed to integrate the Armed Forces into the beginning stages of disaster response operations under a DSC-led Federal JTF. ${ }^{52}$ While understandably problematic considering the current tiered national response system described in the National Response Framework (NRF), this recommendation provides a DSC with a defined authority to request Title 10 forces prior to soliciting Title 32 support, and only for a predetermined period of 72 hours following the DSC's activation to remain consistent with current policy associated with similar actions under Immediate Response Authority. ${ }^{53}$ Table 3 illustrates the conceptual model for preliminary Armed Forces integration under a DSC-led Federal JTF. This process is permitted up to 72 hours after DSC activation. The normal Request For Assistance (RFA) process begins at the conclusion of the proposed 72-hour integration period. 


\begin{tabular}{|l|l|l|}
\hline \multicolumn{1}{|c|}{ Level 1-Reactive } & \multicolumn{1}{c|}{ Level 2-Integrated } & \multicolumn{1}{c|}{ Level 3-Collaborative } \\
\hline $\begin{array}{l}\text { R1: DCO/DCOIC identifies } \\
\text { and prioritizes civil authority } \\
\text { requests for assistance (RFA) } \\
\text { based on urgency of need, } \\
\text { severity, and extent of required } \\
\text { capability }\end{array}$ & $\begin{array}{l}\text { I1: Establish communications } \\
\text { link between DSC-led Federal } \\
\text { JTF, DCO/DCOIC, and } \\
\text { selected units of the Armed } \\
\text { Forces for pending support }\end{array}$ & $\begin{array}{l}\text { C1: DSC-led Federal JTF } \\
\text { assumes tactical control } \\
\text { of Armed Forces units and } \\
\text { coordinates support activities }\end{array}$ \\
\hline $\begin{array}{l}\text { R2: Assess RFAs and flag } \\
\text { specific tasks for DoD support }\end{array}$ & $\begin{array}{l}\text { I2: DCO/DCOIC confirms } \\
\text { capability requirements with } \\
\text { requesting lead Federal civil } \\
\text { authority }\end{array}$ & $\begin{array}{l}\text { C2: DSC-led Federal JTF assigns } \\
\text { forces missions based on } \\
\text { RFAs though National Incident } \\
\text { Management System process }\end{array}$ \\
\hline $\begin{array}{l}\text { R3: Coordinate with DSC- } \\
\text { led Federal JTF to determine } \\
\text { appropriate DoD resources to } \\
\text { fulfill RFAs }\end{array}$ & $\begin{array}{l}\text { I3: SECDEF deploys units of } \\
\text { the Armed Forces to DSC-Ied } \\
\text { Federal JTF }\end{array}$ & $\begin{array}{l}\text { C3: DSC-led Federal JTF } \\
\text { integrates Title 10 forces into } \\
\text { mission command structure } \\
\text { and missions according to } \\
\text { civilian priorities }\end{array}$ \\
\hline
\end{tabular}

\section{Table 3. Temporary Title 10 Integration Maturity Model.}

\section{Maturity Model Example 3: Designate and Deploy a Title 10 Adaptive Task Force.}

Similar to the proposed initial Title 10 integration period discussed earlier, we also proposed the identification and inclusion of a Federal adaptive task force (A-TF) during future DSC-led support operations. ${ }^{54}$ The proposed A-TF, like the Title 10 integration period, is intended to minimize bureaucratic restrictions and maximize the DSC's decisionmaking flexibility. Using the actions of Task Force (TF) Pump during Sandy as an example, we recommend designatingwhere needed and appropriate - a single Federal TF to perform a defined set of missions based on capability requirements determined by the DSC-led Federal JTF, DCO, and requesting lead Federal civil authori- 
ties. In Sandy, TF Pump provided the NY DSC with an easily identifiable unit with a focused capability (dewatering). TF Pump received most mission assignments related to dewatering in and around New York City during the Sandy response. According to the NY DSC, TF Pump offered a single decision point for dewatering missions that simplified matters and resulted in quicker response. The A-TF simply codifies this ad hoc model used during Sandy as a default requirement during future DSC response efforts. The maturity model for assigning and deploying an A-TF is illustrated in Table 4.

\begin{tabular}{|l|l|l|}
\hline \multicolumn{1}{|c|}{ Level 1-Reactive } & \multicolumn{1}{|c|}{ Level 2-Integrated } & Level 3-Collaborative \\
\hline $\begin{array}{l}\text { R1: Federal DCO coordinates with } \\
\text { lead Federal civil authorities, FEMA, } \\
\text { to identify major mission capability } \\
\text { (ex. Dewatering) }\end{array}$ & $\begin{array}{l}\text { I1: NORTHCOM identifies/ } \\
\text { designates DSC-led Federal JTF } \\
\text { and provides forces to JTF }\end{array}$ & $\begin{array}{l}\text { C1: DSC-led Federal } \\
\text { JTF task organizes } \\
\text { military forces based on } \\
\text { mission analysis, using } \\
\text { either a functional or } \\
\text { geographical model for } \\
\text { subordinate JTF/TFs }\end{array}$ \\
\hline $\begin{array}{l}\text { R2: DSC-led Federal JTF } \\
\text { communicates needed mission } \\
\text { capability to NORTHCOM }\end{array}$ & $\begin{array}{l}\text { I2: NORTHCOM issues prepare } \\
\text { to deploy orders for requested } \\
\text { military forces }\end{array}$ & $\begin{array}{l}\text { C2: DSC-led Federal JTF } \\
\text { A-TF and assumes } \\
\text { tactical control of TF } \\
\text { within AOR; assigns } \\
\text { missions as needed }\end{array}$ \\
\hline $\begin{array}{l}\text { R3: DSC-led Federal JTF assesses } \\
\text { response requirement against } \\
\text { available force capability in order to } \\
\text { determine suitable unit }\end{array}$ & $\begin{array}{l}\text { I3: DSC-led Federal JTF either } \\
\text { deploys internal capability } \\
\text { against a requirement or } \\
\text { requests additional capability }\end{array}$ & \\
\hline
\end{tabular}

Table 4. Title 10 Task Force Deployment Maturity Model. 


\section{CONCLUSION}

The above models, although simplistic, offer an alternative method to plan for and execute military civil support operations under the DSC arrangement. Developing METLs is a familiar practice for most military planners and despite their similarities, maturity models are not. Due to the intricacy and uncertainty in most DSCA operations, scripting a mission from beginning to end is unrealistic as requirements and situations often change. Rather than attempting to plan for every possible scenario and burying themselves in detailed plans and orders, commanders and their staffs should instead emphasize the identification and execution of mission-essential tasks as a method for gaining operational maturity. As we have demonstrated, process improvement strategies can provide an alternative approach to enhancing performance during the uncertainty of DSCA response missions. By generating METLs and graphically depicting them in maturity models like the examples above, commanders can reference these tools as guides to effective practice without sacrificing decision-making flexibility.

As discussed, process improvement methods are used extensively in nonoperational DoD business, and in many cases as a universal standard of performance or practice. Process improvement in general has proven to be effective in generating enhancements and contributions to DoD. With such extensive application and utility in DoD business operations, process improvement can and should be considered as a guided method for improving operational maturity as well. The DSC-led DSCA response to Hurricane Sandy demonstrated some of the areas in which process improvement could have been applied. 
While most process improvement strategies are ill-suited to the complexities of DSCA and DSC-led operations for reasons discussed, the maturity model concept offers a different approach to improve future mission execution. In order to achieve more mature DSCA operations under the DSC arrangement, we need mechanisms in place to help commanders and their staffs manipulate-to the extent possible-the various uncertainties represented in the complex decision environment present in most DSCA scenarios. The maturity model concept provides commanders with a method of limiting these uncertainties through a framework that identifies, standardizes, and codifies mission essential tasks in a DSC-led response environment. So, while DSCA operations cannot be scripted, they can be more structured and defined than they are currently. The maturity model concept provides a semi-structured framework for improving future DSCA mission execution. Therefore, DoD should consider the concepts addressed in this monograph and use them as a basis for maturity model development for future DSCA operations. These models can be presented as supplemental material in an appendix to various DoD reference publications, doctrine, directives, and guidance documents relevant to the DSCA mission capability. DoD should leverage the lessons learned from Hurricane Sandy and determine ways to integrate maturity model concepts into future DSCA and DSC training and real-world operations.

To maintain operational effectiveness, DoD must ensure its ability to continually adapt to changing policy and legislation - such as the DSC initiativewithout sacrificing performance during domestic civil support operations. The DSC response to Hurricane Sandy was only the first attempt to use this unique 
coordination mechanism in response to a domestic disaster. There are numerous opportunities for improvement. Emphasizing task performance and processes is the proper approach to improve upon the challenges noted during Sandy. Process improvement strategies provide the foundation for generating such improvements and should be integrated into future dual status commander DSCA operations. Doing so will result in improved coordination between the National Guard and Federal military forces during disaster response, ultimately leading to more lives saved, fewer properties lost, and less suffering during the next significant incident requiring military support.

\section{ENDNOTES}

1. National Defense Authorization Act for fiscal year 2012, Public Law 112-81, H.R. 1540, Sec. 515, p. 98.

2. Department of Defense Instruction 3025.xx: Dual Status Commanders for Defense Support of Civil Authorities, Washington, DC: U.S. Government Printing Office, n.d. (draft).

3. William Prendergast, "Contingency Dual Status Commander: Balancing Title 10 and 32 Responsibilities," Carlisle, PA: U.S. Army War College, March 2011, pp. 1-24; Garrett Jensen, "DoD Disaster Response: Unity of Effort Versus Unity of Command," Carlisle, PA: U.S. Army War College, May 2007, pp. 1-22; Andy Hall, "Improving Military Response to Catastrophic Events within the United States," Carlisle, PA: U.S. Army War College, March 2009, pp. 1-26; Caroline Prosch, "Getting to One from Title 10 + Title 32 Unity of Effort in the Homeland," Monterey, CA: Naval Postgraduate School, September 2011, pp. 1-133; Steven Blum and Kerry McIntyre, Enabling Unity of Effort in Homeland Response Operations, Carlisle, PA: Strategic Studies Institute, U.S. Army War College, April 2012; Ludwig Schumacher, "Dual Status Command for No-Notice Events: Integrating the Military Response to Domestic Disasters," Homeland Security Affairs, Vol. 7, No. 4, February 2011, pp. 1-9; John Gereski and Chris Brown, "Two Hats 
Are Better than One: The Dual-Status Commander in Domestic Operations," The Army Lawyer, June 2010, pp. 72-79.

4. "No-notice/limited-notice" is the DoD accepted vernacular referring to incidents other than planned events of national significance (i.e., national security special events - Super Bowl, political conventions, etc.). According to DoD personnel, the no-notice/ limited-notice designation can often apply to hurricanes, earthquakes, tornadoes, terrorism, etc. Currently, there is no doctrinal distinction between no-notice and limited-notice.

5. Previous to Sandy, there were five past incidents in which a DSC was activated to lead the response: Hurricane Irene, two for Hurricane Isaac, one for the 2012 CA wildfires, and one for the CO (Waldo Canyon) wildfire. None of these incidents received Title 10 forces - only National Guard forces, so the DSCs were dissolved quickly.

6. Charles Jacoby and Frank Grass, "Dual Status, Single Purpose: A Unified Military Response to Hurricane Sandy," pp. 1-2, available from www.ang.af. $\mathrm{mil} /$ news/story.asp?id=123339975, accessed October 11, 2013.

7. The military now has a Joint Lessons Learned Information System (JLLIS) which all services can use and provide lessons learned input, but it is only as good or valuable as the units inputting the data and/or using JLLIS as a source for future operational improvements.

8. Mary Beth Chrissis, Mike Conrad, and Sandy Shrum, CMMI Second Edition: Guidelines for Process Integration and Product Improvement, Boston, MA: Pearson, 2007; Suzanne Garcia and Richard Turner, CMMI Survival Guide: Just Enough Process Improvement, Boston, MA: Pearson, 2007; Dennis Ahern, Aaron Clouse, and Richard Turner, CMMI Distilled: A Practical Introduction to Integrated Process Improvement, Upper Saddle River, NJ: Addison-Wesley, 2008.

9. U.S. Constitution, Art. I, Sect. 8.

10. Ibid., Art. II, Sect. 2. 
11. For details, see 2012 Atlantic Hurricane Season, p. 4, available from www.nhc.noaa.gov/data/tcr/summary_atlc_2012.pdf.

12. Interviews conducted by the author with various DoD employees, January-March 2014. For details, also see "The Department of Defense Prepares for Hurricane Sandy," Release No: 854-12, October 27, 2012, available from www.defense.gov/releases/ release. aspx? releaseid $=15646$.

13. Interviews conducted by the author with various DoD employees, National Guard officers, and active military officers who participated in the response to Hurricane Sandy in some capacity, January-March 2014; Jacoby and Grass, p. 2.

14. "Homeland Defense: DOD Needs to Address Gaps in Homeland Defense and Civil Support Guidance," Report to Senate Committee on Homeland Security and Governmental Affairs, \#13-128, Washington, DC: U.S. Government Accountability Office (USGAO), October 2012, p. 1.

15. Hurricane Katrina in 2005 was a multistate response effort. However, while proposed at the time, a DSC was not used during the response.

16. Interviews conducted by the author with various DoD employees, National Guard officers, and active military officers who participated in the response to Hurricane Sandy.

17. DoD Directive 3025.18, Defense Support of Civil Authorities, discusses DoD policy for Immediate Response Authority (IRA), Washington, DC: DoD, Sect. 4, subsect. g, p. 4. The current IRA policy reads:

In response to a request for assistance from a civil authority, under imminently serious conditions and if time does not permit approval from higher authority, DoD officials may provide an immediate response by temporarily employing the resources under their control, subject to any supplemental direction provided by higher headquarters, to save lives, prevent human suffering, or mitigate great property damage within the United States. 
18. Various DoD after action reports provided to the authors suggest Title 10 unit commanders were unaware of the DSC construct or how federal military forces were to integrate into the joint structure.

19. "Fragmentary Order" is defined by Joint Publication (JP) 1-02, Department of Defense Dictionary of Associated Military Terms as "An abbreviated form of an operation order issued as needed after an operation order to change or modify that order or to execute a branch or sequel to that order." JP 1-2, Washington, DC: USGAO, 2014, p. 105.

20. Copied material from NORTHCOM guidance (fragmentary order) of November 2, 2012.

21. "Hurricane Sandy Disaster Response Active Collection Lessons Learned," United States Fleet Forces Command (USFFC), February 22, 2013; "Hurricane Sandy Response," United States Northern Command (NORTHCOM), 2012, pp. 22-23; Naval Warfare Development Command (NWDC) NEXT, Vol. 1, Issue 1, "Lessons Learned from Hurricane Sandy," Spring 2013, pp.10-14; "Hurricane Sandy Response Hotwash After Action Report," Naval Warfare Development Command, November 30, 2012, pp. 1621; Office of the Secretary of Defense After Action Review - Hurricane Sandy, January 10, 2013, p. 32; Interviews conducted by the author with various DoD employees, including those within the Office of the Assistant Secretary of Defense for Homeland Defense and America's Security Affairs, and United States Northern Command (NORTHCOM), January-March 2014.

22. Ibid.

23. “Civil Support: Actions Are Needed to Improve DoD's Planning for a Complex Catastrophe," Report to Senate Committee on Homeland Security and Governmental Affairs, \#13-763, Washington, DC: USGAO, September 2013, p. 20.

24. Government Accountability Office, \#13-128, 2012.

25. Ryan Burke and Sue McNeil, Toward a Unified Response: Hurricane Sandy and the Dual Status Commander, Carlisle, PA: Strategic Studies Institute, U.S. Army War College, forthcoming. 
26. An Execute (or execution) Order (EXORD) is simply an order issued to initiate military operations as directed by the President of the United States. There are numerous EXORDs originating from the Office of the Chairman of the Joint Chiefs of Staff that cover a variety of military operations.

27. According to JP 1-02, an area of responsibility (AOR) is a geographical area associated with a combatant command within which the geographic combatant commander has authority to plan and conduct operations. Washington, DC: USGAO, 2014, p. 19. As the tactical commander on the ground during a domestic disaster response, the DSC represents the combatant command (USNORTHCOM) and its commander.

28. 10 U.S.C § 12304a, “Army Reserve, Navy Reserve, Marine Corps Reserve, and Air Force Reserve: order to active duty to provide assistance in response to a major disaster or emergency."

29. 32 U.S.C. § 502: "Required drills and field exercises." Subsection $f$ states that members of the National Guard may: "be ordered to perform training or other duty ... (2) that may include ... (A) support of operations or missions undertaken by the member's unit at the request of the President or Secretary of Defense."

30. Jacoby and Grass, p. 2.

31. Blum and McIntyre, p. 31.

32. Chrissis, Conrad, and Shrum, p. 628.

33. Ibid.

34. Ibid., pp. 119-148; Garcia and Turner; Ahern, Clouse, and Turner; as well as the author's personal experience working for and discussions with personnel in some of the noted companies.

35. Interview conducted by the author with a FedEx executive, June 2014.

36. Ibid. For more, also see "FedEx Ground Meets Rising Customer Expectations by Shortening Its Package Processing Cycle," pp. 1-4, 2007, available from ftp://public.dhe.ibm.com/software/solutions/pdfs/ODC00297-USEN-00.pdf. 
37. More about DoD is available from www.defense.gov/about/.

38. Deputy Secretary of Defense Memorandum, DoD-Wide Continuous Process Improvement (CPI) / Lean Six Sigma (LSS), Washington, DC: Department of Defense, April 30, 2007, pp. 1-2; Department of Defense, DoD Instruction 5010.43: Implementation and Management of the DoD-Wide Continuous Process Improvement/ Lean Six Sigma (CPI/LSS) Program, Washington, DC: U.S. Government Printing Office, July 17, 2009, p. 1-21.

39. Bill Curtis, William Hefley, and Sally Miller, People Capability Maturity Model (P-CMM) Version 2.0, Pittsburgh, PA: Carnegie Mellon University Software Engineering Institute, 2001, p. 8; Chrissis, Conrad, and Shrum, pp. 5-8.

40. Curtis, Hefley, and Miller; Ahern, Clouse, and Turner; Chrissis, Conrad, and Shrum; Garcia and Turner.

41. Chrissis, Conrad, and Shrum, p. 5.

42. Brian Mansir and Nicholas Schacht, Total Quality Management: A Guide to Implementation. Defense Technical Information Center Report AD-A232 070, Bethesda, MD: Department of Defense, Logistics Management Institute, 1989.

43. John Davis, Lean Manufacturing: Implementation Strategies that Work: A Roadmap to Quick and Lasting Success, New York: Industrial Press, 2009.

44. Peter Pande, Robert Neuman, and Roland Cavanagh, The Six Sigma Way: How GE, Motorola, and Other Top Companies are Honing Their Performance, New York: McGraw-Hill, 2000.

45. The IDEAL Model, Pittsburgh, PA: Software Engineering Institute, Carnegie Mellon University, 2009, available from resources.sei.cmu.edu/asset_files/Presentation/2001_017_001_23277.pdf.

46. Chrissis, Conrad, and Shrum.

47. Headquarters, United States Marine Corps, Department of the Navy, Marine Corps Doctrinal Publication 6, Command and Control, Washington, DC: U.S. Government Printing Office, Octo- 
ber 1996, pp. 79-81; Headquarters, Department of the Army, Army Doctrine Reference Publication 6-0, Mission Command, Washington DC: U.S. Government Printing Office, May 2012, pp. 2-1 - 2-17.

48. Department of Defense, Joint Chiefs of Staff, Joint Mission Essential Task List Development Handbook, Washington DC: U.S. Government Printing Office, September 2002.

49. Advisory Panel on Department of Defense Capabilities for Support of Civil Authorities After Certain Incidents, Before Disaster Strikes: Imperatives for Enhancing Defense Support of Civil Authorities, Report to the Secretary of Defense and Committees on Armed Services, Washington, DC: RAND Corporation, September 15, 2010, p. 21.

50. Tonia De Bruin, Ronald Freeze, Uday Kaulkarni, and Michael Rosemann, "Understanding the Main Phases of Developing a Maturity Assessment Model," paper presented at the Queensland University of Technology, "16th Australasian Conference on Information Systems," Sydney, Australia, November 29-December 2, 2005, pp. 6-8.

51. Burke and McNeil, pp. 62-63.

52. Ibid., pp. 63-66.

53. DoD Directive 3025.18 outlines the policy for conducting IRA. This policy authorizes federal military commanders to provide immediate response at the request of a civil authority and without prior approval for up to 72 hours.

54. Burke and McNeil, pp. 68-69. 


\title{
U.S. ARMY WAR COLLEGE
}

\author{
Major General William E. Rapp \\ Commandant
}

\section{***** \\ STRATEGIC STUDIES INSTITUTE and U.S. ARMY WAR COLLEGE PRESS}

Director

Professor Douglas C. Lovelace, Jr.

Director of Research

Dr. Steven K. Metz

Authors

Mr. Ryan Burke

Dr. Sue McNeil

Editor for Production

Dr. James G. Pierce

Publications Assistant

Ms. Rita A. Rummel

*****

Composition

Mrs. Jennifer E. Nevil 


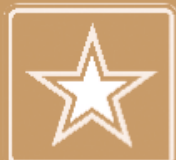

\section{U.S.ARMY}

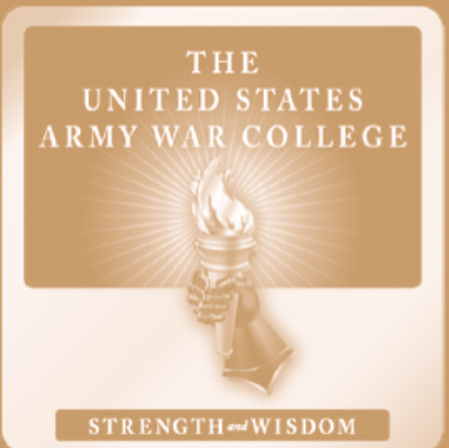

FOR THIS AND OTHER PUBLICATIONS, VISIT US AT http://www.carlisle.army.mil/

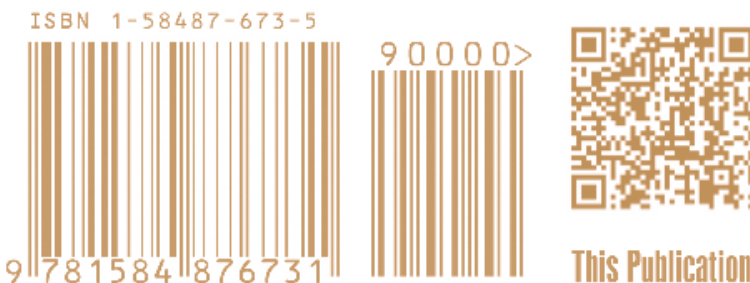

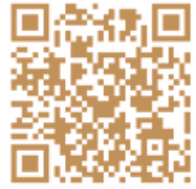

SSI Wensite
口峝口

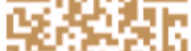
720

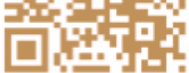

